\title{
PEMEROLEHAN BAHASA DALAM PERSPEKTIF PSIKOLINGUISTIK DAN ALQURAN
}

\author{
Ahmad Muradi \\ Prodi Pendidikan Bahasa Arab Fakultas Tarbiyah dan Keguruan \\ Universitas Islam Negeri Antasari Banjarmasin \\ ahmadmuradi@uin-antasari.ac.id
}

\begin{abstract}
Language acquisition is a process experienced by humans in the development of natural languages. The purpose of this paper is 1) to describe the theory of language acquisition in the perspective of psycholinguistics and the Qur'an, 2) to describe the process of acquiring language in a psycholinguistic and Qur'anic perspective. Three theories carefully discuss the acquisition of this language, namely behavioristic, nativis and functional theory. The behavioristic theory said that the acquisition of language through verbal behavior, that is by responding to stimuli and finally giving rise to language. The nativis theory said that the acquisition of language with genetic capacity influences the ability to understand the language around us, and produces a construct of a language system that is embedded in itself. Functional theory says that language acquisition depends on cognitive development. So, someone based on output language, then process it by giving meaning and finally giving birth to language as input. In the Qur'an, the process of acquiring language through speech and stimulus from outside is then welcomed by the potential that is owned and assisted by existing tools. Humans digest messages that arrive and process them with the thought processes and memories they have and then continue to understand them and ultimately create a 'new' language.
\end{abstract}

Kata Kunci: language acquisition; language input; response; language output

\begin{abstract}
ABSTRAK
Pemerolehan bahasa merupakan proses yang dialami manusia dalam perkembangan bahasa yang bersifat alami. Tujuan penulisan ini adalah 1) mendeskripsikan teori pemerolehan bahasa dalam perspektif psikolinguistik dan Alquran, 2) mendeskripsikan proses pemerolehan bahasa dalam perspektif psikolinguistik dan Alquran. Tiga teori membahas secara cermat terhadap pemerolehan bahasa ini, yakni teori behavioristik, nativis dan fungsional. Teori behavioristik mengatakan bahwa pemerolehan bahasa melalui perilaku verbal, yaitu dengan merespon stimulus dan akhirnya menimbulkan bahasa. Teori nativis mengatakan bahwa pemerolehan bahasa dengan kapasitas genetik yang mempengaruhi kemampuan dalam memahami bahasa di sekitar kita, dan menghasilkan sebuah konstruksi sistem bahasa yang tertanam dalam diri. Teori fungsional mengatakan bahwa pemerolehan bahasa bergantung pada perkembangan kognitif. Jadi, seseorang berdasar output bahasa, lalu memprosesnya dengan memberi makna dan akhirnya melahirkan bahasa sebagai input. Dalam Alquran, proses pemerolehan bahasa melalui ujaran dan stimulus dari luar kemudian disambut oleh potensi yang dimiliki dan dibantu dengan piranti yang ada. Manusia mencerna pesan yang sampai dan mengolahnya dengan proses berpikir dan memori yang dimiliki lalu diteruskan dengan memahaminya dan pada akhirnya tercipta bahasa 'baru'.
\end{abstract}

Kata Kunci: pemerolehan bahasa; input bahasa; respon; output bahasa 


\section{PENDAHULUAN}

Bahasa dalam konteks linguistik dipandang sebagai sebuah sistem bunyi yang arbriter, konvensional, dan dipergunakan oleh manusia sebagai sarana komunikasi. (Kholid A. Harras dan Andika Dutha Bachari, 2009:1). Definsi ini menunjukkan bahwa tidak ada kaitan antara bahasa dengan fenomena lain, artinya ia berdiri sendiri dan ia bertujuan sebagai alat komunikasi. Namun jika bahasa dikaitkan dengan proses pemerolehannya maka bahasa tidak berada secara mandiri melainkan terdapat oknum lain yang terlibat dalam pembentukannya.

Dalam teori kemunculan bahasa dijelaskan bahwa bahasa muncul dengan berbagai sumber baik dari dalam diri manusia maupun dari luar diri manusia. Dari dalam diri manusia maksudnya adalah kemampuan manusia dalam menciptakan bahasa dengan proses yang mesti dilalui berupa respon terhadap rangsangan dari luar berupa gerak dan suara manusia sendiri seperti tertawa, menangis dan lainnya. Sedangkan dengan bahasa berasal dari diri manusia seperti teori bahwa bahasa adalah wahyu Allah Swt dan juga teori interaksi manusia dengan alam, yakni suara dari alam seperti suara hembusan angin, gemercik air, kicauan burung yang ditirukan manusia.

Mengkaji tentang pemerolehan bahasa berarti juga mengkaji tentang perkembangan manusia itu sendiri dari aspek fisik dan psikis. Manusia diberikan anugrah berupa fitrah atau kemampuan untuk berkembang. Perkembangan manusia yang dimaksud adalah perkembangan kognitif, afektif dan psikomotorik yang dimiliki manusia. Aspek bahasa juga berkembang seiring dengan perkembangan ketiga aspek tersebut.

Menurut Nana Jumhana (2014: 110) proses pemerolehan bahasa memberikan gambaran tentang perkembangan salah satu fungsi terpenting pada manusia dan kajian terhadapnya merupakan topik pokok dalam psikolinguistik.

Makalah ini mencoba menelaah garis besar permasalahan dalam pemerolehan bahasa Arab dalam perspektif psikolinguistik dan Alquran. Dengan demikian, yang menjadi pokok masalah dalam penulisan makalah ini adalah 1) Bagaimana teori pemerolehan bahasa dalam perspektif psiklinguistik dan Alquran. 2) Bagaimana proses pemerolehan bahasa dalam perspektif psiklinguistik dan Alquran. Sedangkan 
tujuan penulisan ini adalah 1) untuk mendeskripsikan teori pemerolehan bahasa dalam perspektif psiklinguistik dan Alquran. 2) untuk mendeskripsikan proses pemerolehan bahasa dalam perspektif psikolinguistik dan Alquran.

Pertanyaannya adalah mengapa tulisan ini tidak hanya disorot dengan psikolinguistik tetapi juga dengan Alquran? Jawabannya adalah Alquran merupakan pedoman hidup muslim, ia juga merupakan samudra pengetahuan yang dapat dilihat dari berbagai sudut pandang. Dalam tulisan Ali Sodikin (2008: 12-21), terdapat kajian-kajian tentang Alquran seperti:

\section{Mafhum aN-Nash Dirasah fi Ulum} Alquran yang ditulis Nasr Hamid Abu Zayd. Tulisannya terkait dengan dialektika antara teks (Alquran) dengan konteks (situasi sosial masyarakat) mengungkapkan dialektika tersebut dengan mengkritisi konsep-konsep dalam ilmu-ilmu Alquran klasik.

2. Menggugat Otentisitas Wahyu Tuhan: Kritik Atas Nalar Tafsir Gender yang ditulis oleh Aksin Wijaya mengatakan bahwa kuatnya otoritas tradisi Arab dalam penafsiran terhadap Alquran. Dengan pendekatan linguistik, khususnya linguistik strukturalis dan post-strukturalis, ia menunjukan biasbias tradisi Arab dalam penafsiran terhadap ayat-ayat yang berkaitan dengan kedudukan perempuan.

3. Hubungan Akibat Antara Turunnya Ayat-ayat Alquran dan Adat Kebiasaan dalam Tradisi Kebudayaan Arab Jahiliyah yang ditulis oleh Imam Muchlas. Ia menjelaskan berbagai adat kebiasaan orang Arab dan bagaimana sikap Alquran terhadapnya. Melalui pendekatan sosiologis-antropologis, dia menganalisis keberadaan adat tersebut melalui jalur asbabun nuzul.

4. Ali Sodiqin juga mengadakan kajian terhadap Alquran dalam kacamata antropologi. Ia menjelaskan tentang enkulturasi Alquran terhadap tradisi Arab yang menghasilkan konsep reproduksi kebudayaan yang berdasarkan worldview-nya, yaitu tauhid atau monoteisme dan etika sosial atau moralitas.

Demikian keempat kajian diatas yang juga mengkaji Alquran dalam perspektif yang berbeda. Nasr Hamid dan Aksin Wijaya menggunakan perspektif linguistik dan Muchlas menggunakan perspektif historis sedangkan Ali Soqidin menggunakan perspektif antropologi. Adapun yang penulis lakukan adalah kajian tentang pemerolehan bahasa dalam perspektif psikolinguistik dan Alquran.

\section{PEMBAHASAN}

1. Pengertian Pemerolehan Bahasa 
Kata pemerolehan merupakan kata turunan dari kata oleh (KBBI, 1997:702). Pemerolehan berarti proses, perbuatan, dan cara memperoleh. Pemerolehan disebut dalam bahasa Inggris dengan acquisition yang berarti proses penguasaan bahasa yang dilakukan oleh anak secara alami terhadap bahasa ibunya (native language). Pemerolehan bahasa adalah proses yang berlangsung di dalam otak seorang anak ketika dia memperoleh bahasa pertamanya atau bahasa ibunya. (Abdul Chair, 2003:167). Dari definisi di atas dapat dikatakan bahwa pemerolehan bahasa merupakan proses tertentu yang dilakukan otak manusia dalam memperoleh bahasa yang didapat dari hasil interaksi dari luar lalu kemudian diolah sesuai dengan kemampuan dan pertumbuhan otak manusia.

Proses anak mulai mengenal komunikasi dengan lingkungannya secara verbal disebut dengan pemerolehan bahasa anak. Pemerolehan bahasa pertama (B1) anak terjadi jika anak yang sejak semula tanpa bahasa kini telah memperoleh satu bahasa. Pada masa pemerolehan bahasa anak, anak lebih mengarah pada fungsi komunikasi daripada bentuk bahasanya. Pemerolehan bahasa anak-anak dapat dikataka mempunyai ciri kesinambungan, memiliki suatu rangkaian kesatuan, yang bergerak dari ucapak satu kata sederhana menuju gabungan kata yang lebih rumit.

Pemerolehan bahasa pertama erat sekali kaitannya dengan perkembangan sosial anak dan karenanya juga erat hubungannya dengan pembentukan identitas sosial. Menurut Nana Jumhana (2014:112) mempelajari bahasa pertama merupakan salah satu perkembangan menyeluruh anak menjadi anggota penuh suatu masyarakat. Guru juga memiliki andil dalam mengajarkan bahasa pada anak (Faqihatuddiniyah dan Harun Rasyid 2017). Bahasa memudahkan anak mengekpresikan gagasan, kemauannya dengan cara yang benar-benar dapat diterima secara sosial. Bahasa merupakan media yang dapat digunakan anak untuk memperoleh niali-nilai budaya, moral, agama, dan nila-nilai lain dalam masyarakat. Dalam melangsungkan upaya memperoleh bahasa, anak dibimbing oleh prinsip 'jadilah orang lain dengan sedikit perbedaan', atau 'dapatkan dan perolehlah suatu identitas sosial di dalamnya, dan kembangkan identitas pribadi Anda sendiri’ (Nana Jumhana, 2014: 112)

\section{Teori Pemerolehan Bahasa}

Sebelum penulis membahas tentang teori-teori pemerolehan bahasa, ada baiknya dibahas terlebih dahulu tentang psikologi yaitu ilmu yang membahas tentang diri manusia secara 
umum. Sedangkan psikolinguistik adalah ilmu yang membahas tentang fungsi psikologis bahasa. Jadi terdapat perbedaan dari sisi objek pembahasan dari kedua ilmu tersebut. Sementara itu Effendy (2005:10-12) dalam bukunya Metodologi Pengajaran Bahasa Arab ketika berbicara tentang dasar-dasar teoritis pengajaran bahasa hanya menyebutkan psikologi dan linguistik, sementara itu Effendy tidak membicarakan tentang psikolinguistik sebagai dasar ilmu pemerolehan bahasa.

Untuk lebih jelasnya titik
perbedaan antara psikologi dan
psikolinguistik, berikut penulis kutip
pendapat dari Mamluatul Hasanah
$(2010: 55-56)$ dalam bukunya Proses

Manusia Berbahasa menyatakan:

Pemerolehan bahasa merupakan salah satu bahasan penting yang ada dalam psikolinguistik selain juga psikologi. Ketika membicarakan masalah pemerolehan bahasa agak sulit memang, kalau harus dipilah mana yang menjadi bagian dari psikolinguistik, mana yang menjadi bagian dari psikologi. Kesulitan ini bisa digambarkan ketika misalnya seorang pakar psikologi membahas masalah fungsi psikologis setiap bagian dari manusia, maka dia harus melihat karakteristik dari keadaan yang akan dia deskripsikan fungsi psikologisnya. Dan ketika seorang akan membahas tetang fungsi psikologis bahasa, mau tidak mau harus kembali kepada ilmu bahasa. Meskipun sebenarnya masukan- masukan yang diberikan linguistik belum sepenuhnya bisa menjawab ilmu psikologi. Persoalan ini tidak akan jelas hakekatnya, kecuali kalau hubungan antara bahasa dan fenomena dasar komunikasi manusia terutama yang berkaitan dengan fungsi bahasa sebagai simbol jelas juga hakekatnya.

Selain masalah fungsi bahasa hal yang juga menjadi persoalan adalah, apakah tahapan anak memperoleh bahasa menjadi wilayah kajian psikologi ataukah ilmu bahasa? Bagaimanapun, perkembangan bahasa anak termasuk dalam wilayah psikologi perkembangan. Akan tetapi yang bisa menjawab secara detail proses-proses pemerolehannya, baik semantik sintaksis ataupun fonologinya adalah ilmu bahasa.

Dari pendapat Mamluatul Hasanah di atas, dapat disimpulkan bahwa terdapat tiga cabang ilmu yang masing-masing mempunyai fungsi yang berbeda terkait masalah manusia, yaitu psikologi, linguistik, dan psikolinguistik. Psikologi adalah ilmu yang membahas tentang fungsi psikologis dalam diri manusia. Sedangkan linguistik merupakan ilmu yang membahas tentang proses pemerolehan bahasa. Sementara psikolinguistik adalah ilmu yang membahas tentang yang menjadi potensi atau fitrah pemerolehan bahasa bagi manusia.

Berikut penulis uraikan teori-teori pemerolehan bahasa bagi manusia. 
Douglas Brown (2008: 27-36) membagi teori pemerolehan bahasa bagi manusia kepada tiga, yaitu teori behavioristik, Nativis, dan fungsional.

\section{a. Teori Behavioristik}

Salah satu upaya yang paling masyhur untuk membangun model behavioristik atas perilaku linguistik tertuang dalam karya klasik B. F. Skinner, Verbal Behavior (1957). Behaviorisme adalah aliran psikologi yang mempelajari tingkah laku yang nyata yang dapat diukur secara obyektif. Dan bahasa dalam konsep behavioristik adalah perilaku verbal. Teori ini mendeskripsikan dan menjelaskan perilaku bahasa dengan bantuan model S-R (Stimulus-Respon). Pada teori ini ada hubungan antara situasi stimulus (S) dari luar atau dalam organismenya dan suatu reaksi (R) dari organisme tersebut. Jadi perilaku bahasa yang efektif sebagai wujud tanggapan yang tepat terhadap stimulus. Jika respons tertentu dirangsang berulang-ulang, ia lantas menjadi kebiasaan, atau terkondisikan. Proses perilaku berbahasa dapat dilihat pada bagan 1 berikut:

$\mathrm{S}$ (stimulus) $\rightarrow \mathrm{R}$ (Respons) $\rightarrow$ Bahasa

Bagan 1: Proses perilaku berbahasa

Karena teori behavioristik itu harus menjelaskan kelakukan belajar semua makhluk hidup, maka tidak ada tempat untuk pengertian mentalistik, seperti kesadaran, rencana, maksud, dan konsep. Analisis kelakuan behavioristik didasarkan atas aksioma: 1) semua perilaku merupakan akibat rangsangan faktor-faktor lingkungan, 2) perilaku dapat diubah sesuai dengan perkembangan lingkungan. (Nama Junhana: 2014, 113)

Pada tahun 1968, Skinner mengatakan bahwa berbahasa haruslah ditanggapi sebagai satu respon operan berkondisi terhadap stimulus tersembunyi baik yang internal atau eksternal. (Mamluatul Hasanah: 68) Kondisi operan atau operant conditioning adalah pengkondisian untuk membuat organisme manusia memberi tanggapan, atau operant (berupa kalimat atau ujaran), secara spontan; operant itu dipertahankan (atau dilatih) dengan perangsang tertentu (misalnya, respons positif dari orang lain, baik verbal maupun nonverbal).

Sebagai penjelasan lebih lanjut dari teori ini bisa digambarkan tentang bagaimana seorang bayi mulai berbahasa. Pada tahapan ketika anak memperoleh sistem bunyi bahasa ibunya, semula dia mengucapkan sistem bunyi yang ada di semua bahasa yang ada di dunia ini. Akan tetapi karena lingkungan telah memberikan contoh terus-menerus terhadap sistem bunyi yang ada pada bahasa ibunya, dan dimotivasi terus untuk 
menirukan sistem bahasa ibunya, maka yang akhirnya dikuasai adalah sistem bahasa ibunya. (Mamluatul Hasanah: 6869)

\begin{abstract}
b. Teori Nativis
Istilah nativis diambil dari pernyataan dasar mereka bahwa pemerolehan bahasa sudah ditentukan dari sananya, bahwa kita lahir dengan kapasitas genetik yang mempengaruhi kemampuan kita memahami bahasa di sekitar kita, yang hasilnya adalah sebuah konstruksi sistem bahasa yang tertanam dalam diri kita.
\end{abstract}

Chomsky (1965) mengemukakan adanya ciri-ciri bawaan bahasa untuk menjelaskan pemerolehan bahasa asli pada anak-anak dalam tempo begitu singkat sekalipun ada sifat amat abstrak dalam kaidah-kaidah bahasa tersebut. Sebenarnya setiap manusia memiliki kemampuan belajar bahasa yang dibawa sejak lahir yang disebut dengan jihaz iktisab al-lugah atau Language Acquistion Device (LAD). Menurut Chomsky, proses belajar bahasa adalah proses pembentukan kaidah (rule formation process), bukan proses pembentukan kebiasaan (habit formation process). Ia berpendapat bahwa manusia memiliki apa yang disebut "innate capacity", suatu kemampuan pada dirinya untuk memahami dan menciptakan ungkapan-ungkapan baru. (Mujandto
Sumadi: 1996, 19) inilah kritik Chomsky terhadap teori psikologi behavior yaitu untuk landasan pembelajaran bahasa karena kemampuan bahasa tidak hanya ditentukan oleh faktor dari luar (eksternal), melainkan juga faktor dari dalam (internal).

McNeill dalam Douglas Brown (2008:31) memaparkan LAD meliputi empat perlengkapan linguistik bawaan: 1) kemampuan membedakan bunyi wicara dari bunyi-bunyi lain di lingkungan sekitar. 2) kemampuan menata data linguistik ke dalam berbagai kelas yang bisa disempurnakan kemudian. 3) pengetahuan bahwa hanya jenis sistem linguistik tertentu yang mungkin sedangkan yang lainnya tidak. 4) kemampuan untuk terus mengevaluasi sistem linguistik yang berkembang untuk membangun kemungkinan sistem paling sederhana berdasarkan masukan linguistik yang tersedia.

McNeill dan para peneliti lain dalam tradisi Chomskyan secara meyakinkan berpendapat mengenai sasaran LAD, yang sangat bertolak belakang dengan teori stimulus-respons (S-R) aliran behavioristik yang begitu terbatas dalam menjelaskan kreativitas yang terdapat dalam bahasa anak-anak. (Douglas Brown (2008:31) 
Nana Jumhana (2014:115) menjelaskan bahwa LAD merupakan piranti pemerolehan bahasa. Titik tolaknya adalah perbedaan antara struktur lahir dan struktur batin pada kalimat. Kedua struktur tersebut saling berhubungan melalui transformasi. Tiap kalimat memiliki struktur abstrak di bawah permukaannya dan LAD memungkinkan anak menyusun hipotesis tetang struktur bawah bahasa yang diperolehnya. Anak tidak sadar terhadap proses ini. Hipotesis-hipotesis yang disusun anak tanpa sadar, kemudian dicoba dalam pemakaiannya. Hipotesishipotesis ini terus-menerus dicoba kebenarannya pada data yang dikumpulkan anak selama ia mendengar dan berbicara. Oleh karena itu hepotesishepotesis tersebut diubah dan disesuaikan secara struktur.

Dari proses yang disebut di atas, lama-kelamaan berkembanglah sistem kaidah bahasa anak secara sistematis ke arah sistem kaidah yang dimiliki orang dewasa. Seorang anak menangkap sejumlah ujaran yang sebagian besar tidak gramatikal. Dari korpus yang tidak berstruktur tersebut, yang masuk sebagai input pada LAD, dibentuklah tata bahasa sebagai input. Proses tersebut dapat digambarkan bagan 2 berikut:

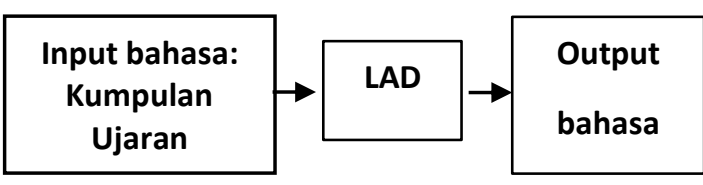

Bagan 2: Proses Pemerolehan Bahasa

Menurut Teori Nativis

Dengan bantuan LAD, seorang anak dapat menemukan struktur batin kalimat-kalimat yang dijumpainya dan kemudian ia dapat membentuk kalimat yang sebelumnya belum pernah dijumpainya. Gramatika yang dibentuk dengan bantuan LAD itu mengandung sifat-sifat khas suatu bahasa tertentu, tetapi di atas itu juga mengandung sifatsifat universal.

\section{c. Teori Fungsional}

Dalam catatan Douglas Brown (2008:35) terdapat pergeseran dalam polapola penelitian tentang bahasa. Pergeseran ini tidak jauh dari matarantai generatif/kognitif menuju esensi bahasa. Dua penekanan muncul: 1) para peneliti mulai melihat bahwa bahasa hanyalah salah satu manifestasi kemampuan kognitif dan afektif manusia dalam kaitannya dengan dunia, orang lain, dan dengan diri sendiri. 2) lebih jauh, kaidahkaidah generatif yang ditawarkan oleh kaum nativis adalah abstrak, formal, eksplisit, dan logis, tetapi mereka hanya bersentuhan dengan bantuk-bentuk bahasa dan tidak dengan makna, sesuatu yang terletak pada tataran fungsional yang lebih 
mendalam yang terbangun dari interaksi sosial. Contoh bentuk-bentuk bahasa adalah morfem kata, kalimat, dan kaidah yang mengatur semua itu. Fungsi adalah tujuan interaktif dan bermakna di dalam suatu konteks sosial (pragmatis) yang penuh dengan bentuk-bentuk.

$$
\text { Gleitman dan Wanner (1982) }
$$

mengatakan dalam tinjauannya atas kemajuan terbaru penelitian bahasa anakanak, "cara anak-anak belajar bahasa dilengkapi dengan kemampuan interpretatif konseptual untuk mengkategorikan dunia. Para pembelajar digiring untuk memetakan tiap-tiap ide semantik atas unit linguistik kata". Dari pendapat Gleitman dan Wanner di atas dapat dikatakan bahwa belajar bahasa tergantung dengan perkembangan kognitif dan kompleksitas bahasa yang dipelajari. Hal ini juga dikatakan Slobin (dalam Douglas Brown: 2008, 37) bahwa dalam semua bahasa, pembelajaran semantik bergantung kepada perkembangan kognitif dan rangkaian perkembangan lebih ditentukan oleh kompleksitas semantik ketimbang kompleksitas struktural. Maknanya, ketika anak memperoleh bahasa dari luar, ia akan memproses bahasa tersebut dengan memahami makna yang sesuai dengan kontek munculnya bahasa tersebut sesuai dengan kemampuan kognitifnya tanpa mengindahkan struktur yang ada.

Berikut proses pemerolehan bahasa menurut teori fungisonal seperti dalam bagan 3:

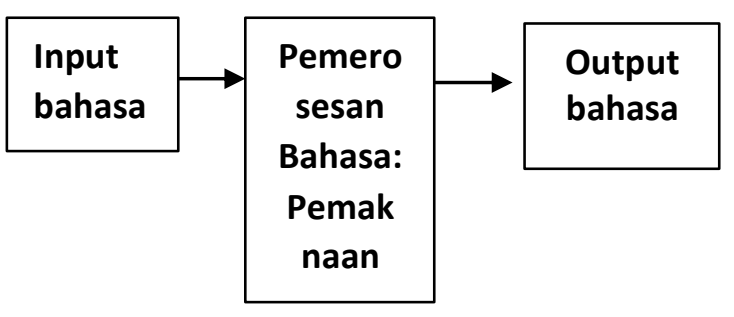

Bagan 3: Proses Pemerolehan Bahasa Menurut Teori Fungsional

Dari bagan 3 di atas dapat dilihat bahwa input bahasa masuk kepada diri manusia untuk diproses dan diberikan pemaknaan tanpa mengindahkan struktur. Lalu kemudian, hasil pemaknaan itu dikeluarkan dengan bahasa sendiri.

3. Pemerolehan Bahasa dalam Perspektif Alquran

Pembahasan tentang pemerolehan bahasa dalam perspektif Alquran terdiri atas lima pembahasan, yaitu fitrah berbahasa dalam Alquran, piranti bahasa dalam Alquran, memori dalam Alquran, dan berpikir dalam Alquran.

a. Fitrah Berbahasa dalam Alquran

Dalam Alquran telah disebutkan tentang potensi manusia dalam berbahasa. Diantara ayat yang menjelaskan hal tersebut adalah Q.S. AlBaqarah/2: 31-32: 


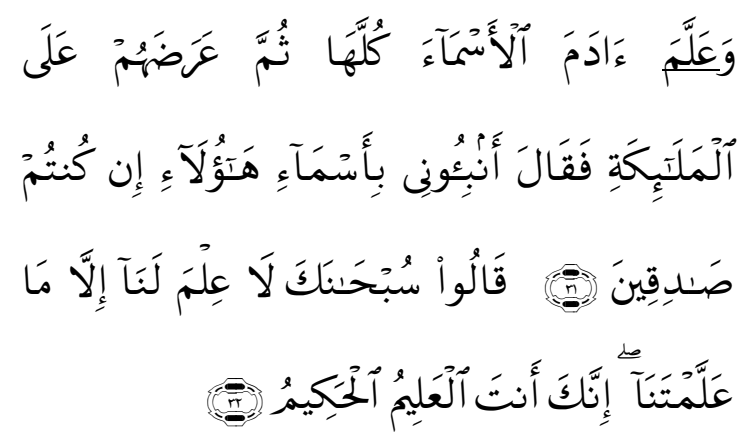

"Dan Dia mengajarkan kepada Adam Nama-nama (benda-benda) seluruhnya, kemudian mengemukakannya kepada Para Malaikat lalu berfirman: "Sebutkanlah kepada-Ku nama benda-benda itu jika kamu mamang benar orang-orang yang benar!" (31) Mereka menjawab: "Maha suci Engkau, tidak ada yang Kami ketahui selain dari apa yang telah Engkau ajarkan kepada kami; Sesungguhnya Engkaulah yang Maha mengetahui lagi Maha Bijaksana". (32)

Ayat di atas menjelaskan bahwa Nabi Adam As telah diberikan pelajaran mengenai nama-nama atas benda-benda yang ada disekitarnya. Maka, dengan demikian telah terjadi komunikasi berbahasa antara Allah Swt. dengan Nabi Adam As. Jadi ayat tersebut juga menunjukkan bahwa manusia (dalam hal ini Adam As.) memiliki potensi untuk berbahasa.

Juga dalam Q.S. Al-Nisa/4:164:

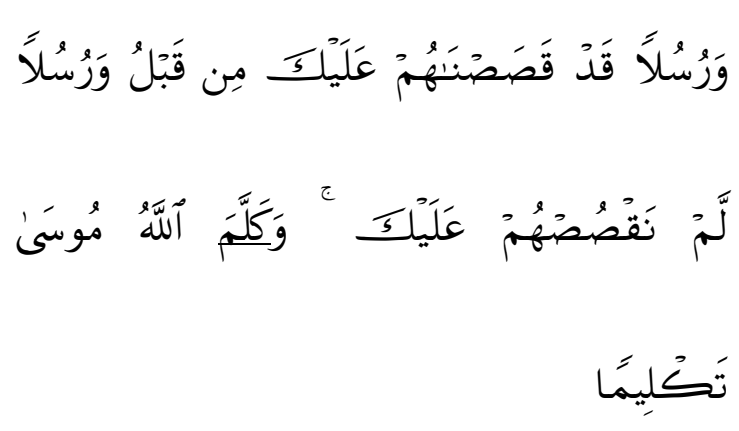

"Dan (kami telah mengutus) Rasul-rasul yang sungguh telah Kami kisahkan tentang mereka kepadamu dahulu, dan Rasul-rasul yang tidak Kami kisahkan tentang mereka kepadamu. dan Allah telah berbicara kepada Musa dengan langsung”

Pada ayat di atas (Q.S. alNisa/4:164) menyatakan telah terjadi interaksi komunikasi dengan ungkapan "kallama" bahwa Allah Swt. telah berbicara dengan Nabi Musa As. Secara langsung. Jadi, dengan demikian dapat dikatakan bahwa manusia telah memiliki potensi yang sudah dipersiapkan Allah Swt. untuk menerima wahyu-Nya melalui kalam untuk dilaksanakan dan disampaikan kepada umat manusia.

Dari penjelasan di atas tentang fitrah/potensi yang ada, manusia diberi kemampuan untuk berbahasa dan siap menerima, merespon serta mengolahnya sehingga ia dapat memahami pesan yang sampai kepadanya dan dapat mengirimkan pesan baru kepada lawan bicara. 
b. Piranti Bahasa dalam Alquran

Dalam Alquran terdapat empat ayat pada empat surah yang berbeda mengenai piranti bahasa atau alat yang digunakan dalam proses berbahasa. Empat ayat dan empat surat yang dimaksud adalah:

1. Surah al-Nahl/68: 78

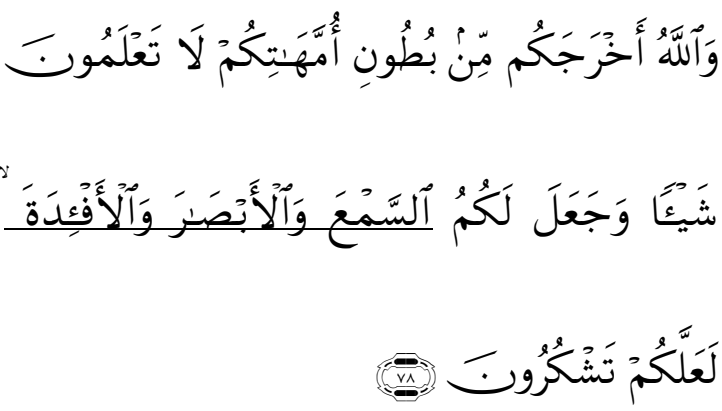

"Dan Allah mengeluarkan kamu dari perut ibumu dalam Keadaan tidak mengetahui sesuatupun, dan Dia memberi kamu pendengaran, penglihatan dan hati, agar kamu bersyukur."

2. Surah al-Mukminun/23: 78

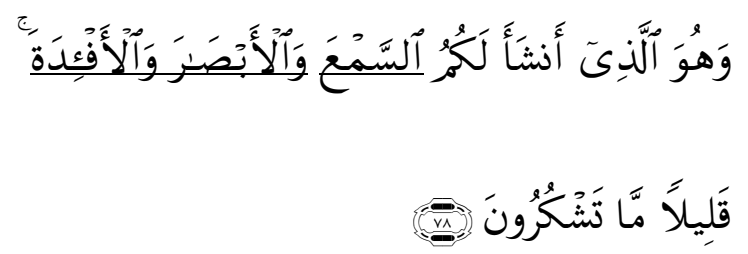

"Dan Dialah yang telah menciptakan bagi kamu sekalian, pendengaran, penglihatan dan hati. Amat sedikitlah kamu bersyukur."

3. Surah al-Mulk/67:23
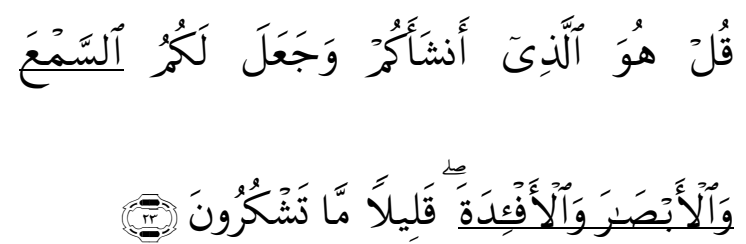

"Katakanlah: "Dia-lah yang menciptakan kamu dan menjadikan bagi kamu pendengaran, penglihatan dan hati". (tetapi) Amat sedikit kamu bersyukur."

4. Surah al-Sajadah/32: 9

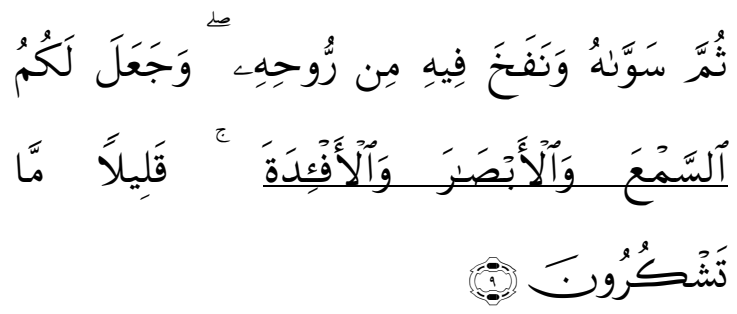

"Kemudian Dia menyempurnakan dan meniupkan ke dalamnya roh (ciptaan)Nya dan Dia menjadikan bagi kamu pendengaran, penglihatan dan hati; (tetapi) kamu sedikit sekali bersyukur."

Dari empat di atas dengan redaksi yang hampir serupa menyebutkan tiga piranti bahasa bagi manusia yaitu sam'a (pendengaran), abshar (penglihatan) dan af'idah (hati). Meski dalam sudut pandang struktur tubuh manusia bahwa ketiga piranti itu pancaindra manusia, namun dalam pandangan ilmu bahasa bahwa ketiga piranti itu merupakan alat untuk dapat berkomunikasi dan memperluas pengetahuan yang dengan sendirinya turut dapat mengembangkan bahasa. Sebab melalui suara dan bunyi yang didengar akan menjadi stimulus atau rangsangan dari luar bagi manusia untuk memprosesnya. Lalu kemudian dipahami pesan yang sampai melalui penglihatan dan fungsi hati yaitu pemahaman itu sendiri dalam diri manusia. 
Berikut penjelasan Alquran mengenai fungsi penglihatan yaitu dengan melihat ayat-ayat Allah Swt. untuk menjadi renungan, pelajaran dan i'tibar bagi manusia dalam mengarungi hidup di dunia. Ayat yang dimaksud adalah Q.S. Fuhsshilat/41:53:

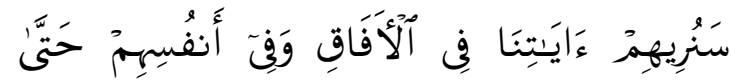

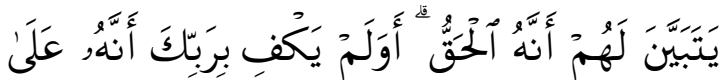

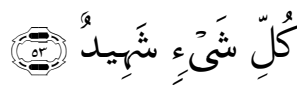

'Kami akan memperlihatkan kepada mereka tanda-tanda (kekuasaan) Kami di segala wilayah bumi dan pada diri mereka sendiri, hingga jelas bagi mereka bahwa Al Quran itu adalah benar. Tiadakah cukup bahwa Sesungguhnya Tuhanmu menjadi saksi atas segala sesuatu?"

Jadi ayat di atas mengisyaratkan bahwa Allah Swt. memerintahkan kepada manusia untuk mempergunakan penglihatannya dengan melihat dan memperhatikan tanda-tanda (kekuasaan) Allah Swt. Sehingga dengan demikian manusia terus merasa bersyukur atas anugerah yang diberikan dan mempergunakannya sesuai dengan tuntutnan dan pedoman dari Allah Swt. dan Rasul-Nya. Namun jika manusia tetap membangkang dengan tidak bersyukur dan tidak mempergunakan piranti tersebut akan mendapatkan murka dari Allah Swt. yaitu pada surat alA'raaf/7 ayat 179 :

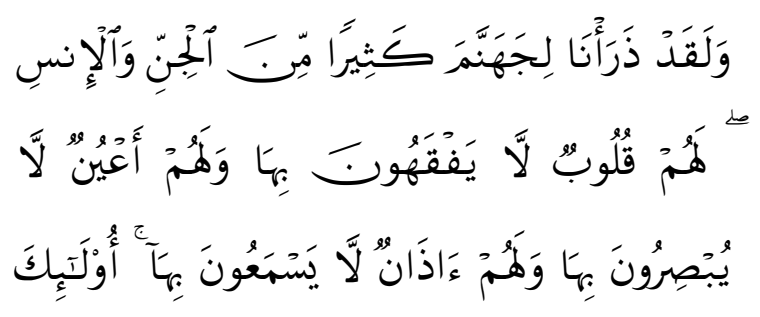

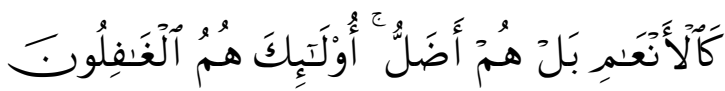

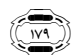

"Dan Sesungguhnya Kami jadikan untuk (isi neraka Jahannam) kebanyakan dari jin dan manusia, mereka mempunyai hati, tetapi tidak dipergunakannya untuk memahami (ayat-ayat Allah) dan mereka mempunyai mata (tetapi) tidak dipergunakannya untuk melihat (tandatanda kekuasaan Allah), dan mereka mempunyai telinga (tetapi) tidak dipergunakannya untuk mendengar (ayatayat Allah). Mereka itu sebagai binatang ternak, bahkan mereka lebih sesat lagi. Mereka itulah orang-orang yang lalai."

Dari penjelasan tiga ayat di atas tentang piranti bahasa yang dimiliki manusia dapat dikatakan bahwa manusia dengan piranti yang ada telah siap menerima dan mengolah pesan yang disampaikan kepadanya.

\section{c. Memori dalam Alquran}

Daya ingat (memori) mempunyai posisi yang penting dalam kehidupan manusia, sebab ingatan dapat membantu seorang manusa menghadapi sebuah 
persolan yang sedang dihadapi, dan membantu manusia untuk merancang masa depan. Selain itu ingatan juga membantu manusia untuk memperoleh informasi-informasi baru, mengungkap realitas-realitas baru yang semuanya dapat meningkatkan ilmu pengetahuan dan budaya manusia. (Mamluatul Hasanah: $2010,122)$

Selain fungsi diatas, ingatan juga punya posisi penting dalam beragama. Manusia selalu dianjurkan oleh Alquran untuk selalu mengingat Allah, tanda-tanda kekuasaan-Nya yang terdapat di alam semesta. Berikut beberapa ayat yang menunjukkan betapa pentingnya mengingat sebagai alat untuk mengambil pelajaran.

Surat Ibrahim/41:52

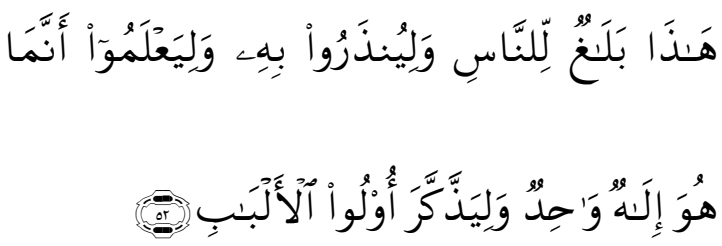

"(Al Quran) ini adalah penjelasan yang sempurna bagi manusia, dan supaya mereka diberi peringatan dengan-Nya, dan supaya mereka mengetahui bahwasanya Dia adalah Tuhan yang Maha Esa dan agar orang-orang yang berakal mengambil pelajaran."
Surat al-Qashash/28:46

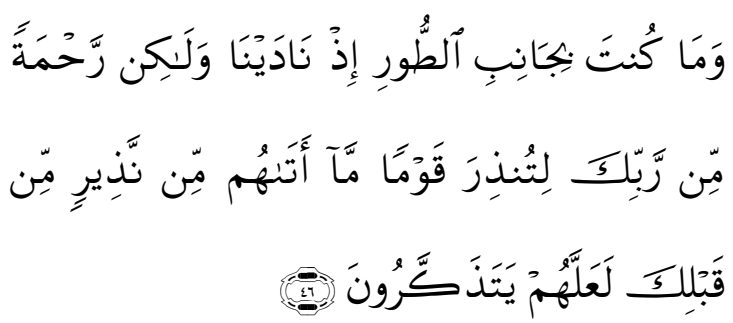

"Dan Tiadalah kamu berada di dekat gunung Thur ketika Kami menyeru (Musa), tetapi (kami beritahukan itu kepadamu) sebagai rahmat dari Tuhanmu, supaya kamu memberi peringatan kepada kaum (Quraisy) yang sekali-kali belum datang kepada mereka pemberi peringatan sebelum kamu agar mereka ingat."

Surat al-Dukhan/44:58

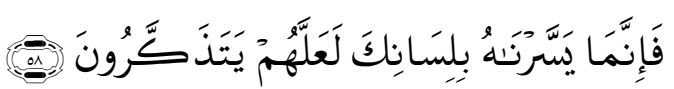

"Sesungguhnya Kami mudahkan Al Quran itu dengan bahasamu supaya mereka mendapat pelajaran."

Kemampuan lain yang diberikan Allah Swt. kepada manusia adalah kemampuan mengingat. Dengan kemampuan ini manusia dapat mereproduksi dan mengolah kembali pesan/bahasa yang telah diterima. Lalu kemudian diujarkan atau disampaikan kepada lawan bicara.

\section{d. Berpikir dalam Alquran}

Berbahasa adalah proses mengeluarkan pikiran dan perasaan (dari otak) secara lisan. Proses berbahasa ini 
melibatkan berbagai organ yang terkait, baik pendengaran, alat ucap lisan, dan otak sebagai pusat penyimpanan dan sekaligus pengolah materi berbicara. Setiap orang memiliki kualitas organ yang berbeda. Bagi orang yang normal tentu dapat berbahasa dengan baik. Sebaliknya, bila terjadi kelainan fungsi otak dan alat bicaranya, tentu mereka mempunyai kesulitan untuk berbahasa, baik produktif maupun reseptif. Dalam proses berbahasa tersebut tidak hanya alat organ yang terlibat, tetapi juga proses mental manusia. (Rohmani Nur Indah dan Abdurrahman, 2008: 51). Jadi dari pernyataan di atas bahwa berpikir merupakan bagian penting dalam berbahasa. Sebab ketika seorang akan berbicara, maka ia akan memproses bahan bicara dengan cara berpikir dalam hati dan kemudian ia ucapkan pesan yang ingin disampaikan kepada lawan bicara.

\section{Dalam Kamus Besar Bahasa} Indonesia disebutkan bahwa kata pikir adalah akal budi; ingatan; kata dalam hati. Sedang berpikir adalah menggunakan akal budi untuk mempertimbangkan dan memutuskan sesuatu; menimbangnimbang dalam ingatan.(KBBI: 1997:682)

Pengertian 'berpikir' dalam kamus Lisan Arab, adalah mendayagunakan khatir (suara hati, benak, jiwa) dalam memahami sesuatu. (Ibnu Manzhur:
Maktabah Syamilah). Dalam Mu'jam alWasith, berpikir berarti menggunakan akal terhadap sesuatu dan menyusun hal-hal yang sedang dipelajari itu agar bisa memahami sesuatu yang belum diketahui. (Ibrahim Mustofa: Maktabah Syamilah). Pikiran adalah wadah yang memuat imajinasi, ilusi dan ingatan. Pikiran adalah sesuatu yang bersifat maknawi (immaterial) yang memiliki pengaruh materiil, sebab semua fenomena kehidupan bisa tertangkap oleh akal. Berpikir bersifat fitrah yang melekat pada manusia dan dengan sifat itu manusia berusaha memenuhi kebutuhannya. Sedang pikiran adalah aktivitas pikiran.

Berpikir merupakan salah satu fungsi kejiwaan manusia yang tidak dimiliki oleh makhluk selain manusia. Oleh karena itu, melalui berpikir manusia dapat menciptakan kemajuan peradaban atau kebudayaan yang selalu berkembang, dan dengan berpikir itu pula manusia mampu beragama dan bertingkah laku susila. Berpikir erat hubungannya dengan daya-daya jiwa yang lain, seperti tanggapan, ingatan, pengertian, dan perasaan. Tanggapan memegang peranan penting dalam berpikir, meskipun ada kalanya dapat mengganggu jalannya pikiran. Ingatan merupakan syarat-syarat yang harus ada dalam berpikir, karena memberikan pengalaman-pengalaman dan 
pengalaman yang telah lampau. Perasaan selalu menyertai pula, ia merupakan dasar yang mendukung suasana hati, atau pemberi keterangan dan ketekunan yang dibutuhkan untuk memecahkan masalah.

Jadi, pengertian berpikir adalah menggunakan pikiran untuk merenung dan menafsirkan segala urusan dunia maupun agama. Ia merupakan aktivitas manusia yang alatnya menggunakan akal, buahnya berupa pendapat, ilmu dan pengetahuan. Aktivitas berpikir tersebut melahirkan filsafat, sehingga filsafat hanyalah hasil pemikiran akal dan hati manusia. Bisa dikatakan bahwa filsafat merupakan hasil menjadi-sadarnya manusia mengenai dirinya sendiri sebagai pemikir, dan menjadi-kritisnya manusia terhadap dirinya sendiri sebagai pemikir di dalam dunia yang dipikirkannya. (Louis O. Kattsoff: 2004,7)

Berpikir kita lakukan untuk menghadapi dan memahami realitas dengan menarik kesimpulan dan meneliti berbagai kemungkinan penjelasan dari realitas eksternal dan internal. Sehingga, mengenai hal ini, Taylor (1977) mendefiniskan berpikir sebagai proses penarikan kesimpulan.

(Eri

Kurniawan:2002,12)

Dalam kehidupan beragama manusia tidak akan dapat menghayati ajaran agamanya dan bahkan keyakinan tentang adanya Tuhan sedalam-dalamnya, tanpa menggunakan akal pikiran sebaikbaiknya. Dalam hal ini Nabi bersabda bahwa "Agama adalah akal dan tidaklah ada agama bagi orang yang tidak berakal'. 'manusia paling utama adalah manusia yang paling berakal'.

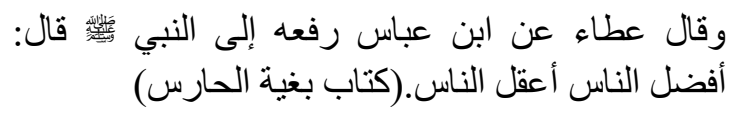

Allah Swt mendorong manusia untuk memikirkan alam, memperhatikan fenomena-fenomena alam yang beragam, serta memikirkan keindahan ciptaan-Nya dan keterpaduan sistem-Nya. Allah Swt mendorong manusia untuk memperoleh ilmu pengetahuan tentang hukum-hukum Allah di semua bidang pengetahuan yang beragam. Dorongan untuk mengadakan observasi, berpikir, meneliti, dan memperoleh ilmu tersebut. Terdapat dalam beberapa ayat Alquran. (Muhammad Utsman Najati: 2005, 216217). Misalnya surah al-Ankabut/29 ayat 20:

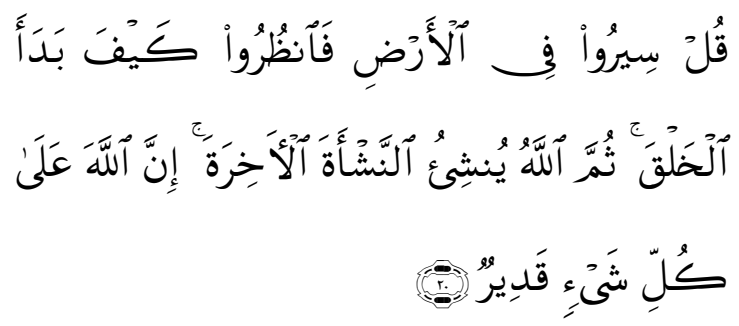

Katakanlah: "Berjalanlah di (muka) bumi, Maka perhatikanlah bagaimana Allah menciptakan (manusia) 
dari permulaannya, kemudian Allah menjadikannya sekali lagi. Sesungguhnya Allah Maha Kuasa atas segala sesuatu."

Surah Yunus/10 ayat 101:

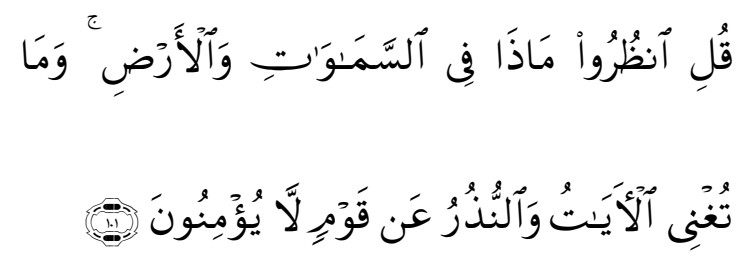

Katakanlah: "Perhatikanlah apa yaag ada di langit dan di bumi. tidaklah bermanfaat tanda kekuasaan Allah dan Rasul-rasul yang memberi peringatan bagi orang-orang yang tidak beriman".

Surah al-Hajj/20 ayat 46:

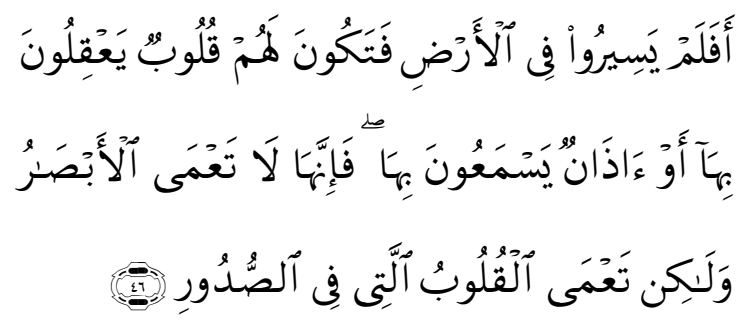

"Maka Apakah mereka tidak berjalan di muka bumi, lalu mereka mempunyai hati yang dengan itu mereka dapat memahami atau mempunyai telinga yang dengan itu mereka dapat mendengar? karena Sesungguhnya bukanlah mata itu yang buta, tetapi yang buta, ialah hati yang di dalam dada".

Kepribadian (Al-Syakhshiyyah) menurut Islam yaitu dalam diri manusia memiliki pola pikir (aqliyah) dan pola sikap (nafsiyyah). pola pikir (aqliyah) adalah mengaitkan fakta (waqi') dan pemahaman sebelumnya (al-ma'lumat alsabiqah) di dalam otak melalui panca indera. Proses berpikir bertujuan untuk menghasilkan sebuah pemahaman. Komponen-komponen berpikir manusia , yaitu adanya 1) Fakta (waqi'), 2) Panca Indera (hawas), 3) Otak (al-dimagh), dan 4) Pemahaman (al-ma'lumat al-sabiqah).

Potensi itulah yang dikehendaki oleh Sang Maha supaya manusia mempergunakannya dengan sebaikbaiknya. Motivasi-motivasi yang Tuhan berikan kepada manusia dengan berbagai ungkapan seperti yang ditampilkan dalam Alquran, yaitu seperti dalam Alquran QS. Yunus/10 ayat 101:

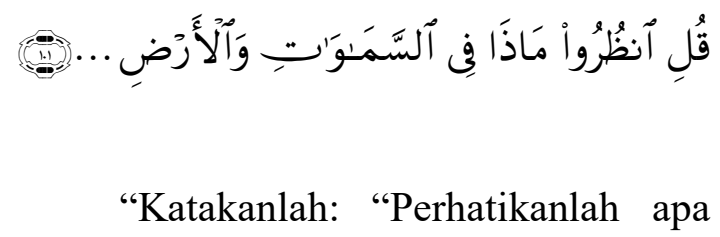
yang ada di langit dan di bumi...”.

Ayat ini mengajak manusia pada sumber pengetahuan (epistemologi) dengan cara memperhatikan, melihat, dan merenung alam.

Jadi, selain memori atau kemampuan mengingat, manusia juga memiliki kemampuan berpikir sebagai alat dalam mencerna, mengolah dan meproduksi kembali pesan/bahasa yang telah sampai kepadanya. Sehingga, 
dengan demikian manusia dapat membuat dan berkreasi dengan bahasa baru.

Berikut bagan proses pemerolehan bahasa dalam perspektif Alquran:

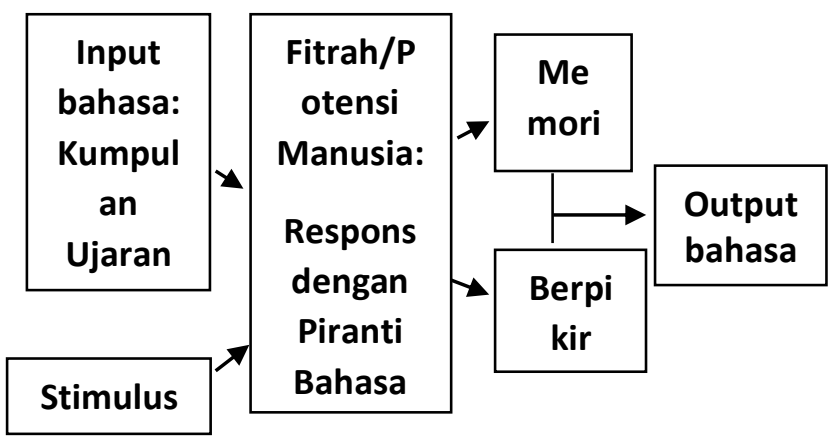

Bagan 4: Proses Pemerolehan Bahasa

Menurut Alquran

Dari bagan 4 di atas, dapat dipahami bahwa sebelum manusia dapat berbahasa, terlebih dahulu ia mendapatkan ujaran dan stimulus dari luar. Dan kemudian disambut oleh potensi yang dimiliki dan dibantu dengan piranti yang ada. Dari situ, manusia mencerna pesan yang sampai, mengolahnya. Lalu diteruskan dengan memahaminya dan pada akhirnya tercipta bahasa 'baru' dan diucapkan kepada lawan bicara.

\section{PENUTUP}

Dari penjelasan di atas, dapat ditarik beberapa simpulan, yaitu:

Bagi teori behavioristik, stimulus atau rangsangan merupakan faktor penentu bagi munculnya respon untuk dapat memperoleh bahasa. Jika stimulus dilakukan terus-menerus dan bentuk positif, maka respon akan mengikutinya dan menirukannya. Artinya dalam berbahasa, menurut teori behavior ini bahwa manusia dapat berbahasa karena adanya stimulus dari luar. Sementara itu, teori nativis bertolak belakang dari teori behavior yang mengatakan bahwa manusia memiliki LAD untuk memperoleh bahasa tanpa bergantung pada stimulus. Maknanya bahwa dalam diri manusia sudah ada potensi yang dapat mengolah dan memproduksi bahasa baru.

Teori ketiga adalah teori fungsional. Dapat dikatakan bahwa teori ini merupakan lanjutan dari nativis. Di mana perbedaannya adalah bahwa bahasa yang diperoleh dari luar akan diproses dengan memberikan pemaknaan tanpa terikat dengan struktur yang sudah ada.

Adapun pemerolehan bahasa dalam perspektif Alquran lebih lengkap dan memuat berbagai potensi dan piranti bahasa yang diperlukan. Tidak sampai di situ saja, namun ditambah dengan kemampuan lain berupa memori dan kemampuan berpikir. Lalu bahasa atau ujaran yang masuk diproses, diolah dan dipahami. Lalu dari hasil pemahaman berupa bahasa 'baru' disampaikan kepada lawan bicara. 


\section{DAFTAR PUSTAKA}

Chaer, Abdul. 2003. Psikolinguistik Kajian Teoritis. Jakarta: Rineka Cipta.

Effendi, Ahmad Fuad. 2005. Metodologi Pengajaran Bahasa Arab. Malang: Misykat.

Faqihatuddiniyah dan Harun Rasyid. 2017. Persepsi orang tua dan guru mengenai bahasa inggris pada anak usia dini di TK ABA Karangmalang Yogyakarta. Jurnal Tarbiyah (Jurnal Ilmiah Kependidikan). Vol.6, No.2.

Harras, Kholid A. dan Andika Dutha Bachari. 2009. Dasar-dasar Psikolinguistik. Bandung: UPIPress.

Hasanah, Mamluatul. Proses Manusia Berbahasa Perspektif al-Qur'an dan Psikolinguistik (Malang: UIN Press, 2010)

Jumhana, Nana. 2004. Pemerolehan Bahasa Pada Anak (Kajian Teoritis Tentang Pemerolehan Bahasa Pertama), Jurnal al-Ittijah, Pendidikan Bahasa Arab Fakultas Tarbiyah dan Keguruan Sultan Maulana Hasnuddin Banten, Volume 6, Nomor 2.

Kamus Besar Bahasa Indonesia Cet-9. 1997. Jakarta: Departemen Pendidikan dan Kebudayaan-Balai Pustaka.

Kattsoff, Louis O. 2004. Pengantar Filsafat. Alih Bahasa: Soejono Soemargono dari Elements Of
Philosophy. Yogyakarta: Tiara Wacana.

Kurniawan, Eri. 2002 Pembudayaan Keterampilan Berpikir Kritis Di Perguruan Tinggi Melalui Cognitive Coaching, Makalah Diajukan untuk memenuhi salah satu syarat Pemilihan Mahasiswa Berprestasi 2002. Universitas Pendidikan Indonesia, Bandung,

Manzhur, Ibnu. Lisan Arab. Maktabah Syamilah, V/65

Mustofa, Ibrahim dkk. Al-Mu'jam alWasith, Maktabah Syamilah, II/311

Najati, Muhammad Utsman. 2005. Psikologi dalam Al-qur'an Terapi Qur'ani Dalam Penyembuhan Gangguan Kejiwaan. Bandung: Pustaka Setia.

Sodiqin, Ali. 2008. Antropologi Al-Quran, Model dialektika Wahyu dan Budaya. Jogjakarta: Ar-Ruzz Media.

Sumardi, Muljanto (ed). 1996. Berbagai Pendekatan dalam Pengajaran Bahasa dan Sastra Jakarta: Pustaka Sinar Harapan.

Rohmani, Nur Indah dan Abdurrahman. 2008. Psikolinguistik, Konsep dan Isu Umumi. Malang: UIN-Malang Press. 